\title{
Analisis Karakteristik Hujan Ekstrim Untuk Mendukung Pengembangan Peringatan Dini Lahar Dingin di Lereng Gunung Merapi
}

\author{
S.Y. Iryani ${ }^{\mathrm{a} *}$ \\ ${ }^{a}$ Universitas Sriwjaya, Jalan raya Prabumulih KM 32 Indralaya, Sumatera Selatan \\ *Corresponding author's e-mail: $\underline{\text { sakurayuliairyani@,ft.unsri.ac.id }}$
}

Received: 20 July 2020; revised: 10 August 2020; accepted: 11 August 2020

\begin{abstract}
Mt. Merapi cold lava disasters in 2010 had caused a lot of public infrastructure and facilities in the area around Mt. Merapi were damaged, due to the occurrence of debris flows triggered by extreme rainfall. Analysis of extreme rainfall characteristics are conducted to determine the pattern of distribution of the amount of hourly rainfall in the slopes of Mt. Merapi. To reduce the negative impact caused by cold lava flood, it is necessary to plan an Early Warning System (EWS) and the proper evacuation measures. EWS based Rainfall intensity, can refer to the Critical Line Curve. The research results showed the greatest rainfall intensity occurred in the Mt. Maron station Pwith the cumulative relative frequency of rainfall intensity $>20 \mathrm{~mm} / \mathrm{hr}$ in between the years 1988 to 2010 with $6.74 \%$. Analysis of the incidence of the most extreme hourly rainfall of 14 rainfall stations in the slopes of Mt. Merapi in 1988 to 2010 occurred in kemasan station in 2010 with $621.5 \mathrm{~mm}$ in January at 6:00 p.m. to 7:00 p.m. Critical Line Curve Kali Gendol rain station Batur, Deles and Sorosan, non-causing rainfall in the dangerous area is 24 events $(13.79 \%)$, causing rainfall in the dangerous area is 4 events $(2.30 \%)$ and non-causing rainfall in the safety area is 146 events $(83.91 \%)$. Cumulative Relative frequency rainfall intensity $>20 \mathrm{~mm} / \mathrm{hr}$ at rainfall stations close to the Kali Gendol i.e. Batur, Deles and Sorosan rainfall station from the highest to the lowest are $2.74 \%, 2.33 \%$ and $1.70 \%$, respectively.
\end{abstract}

Keywords: extreme rainfall, rainfall intensity, early warning system, critical line curve.

Abstrak: Bencana lahar dingin Gunung Merapi menyebabkan banyak infrastruktur publik dan fasilitas bangunan penunjang di sekitar kawasan lereng Gunung Merapi yang rusak akibat terjadinya aliran debris yang dipicu oleh hujan ekstrim di beberapa wilayah. Analisis karakteristik hujan ekstrim dilakukan untuk mengetahui pola sebaran jumlah hujan jam - jaman di wilayah lereng Gunung Merapi. Untuk mengurangi dampak negatif akibat banjir lahar dingin, maka perlu direncanakan suatu sistem peringatan dini atau Early Warning System (EWS) dan tindakan evakuasi yang tepat. EWS berbasis intensitas hujan, dapat mengacu pada kurva garis kritis (Critical Line Curve). Pola spasial hujan ekstrim berdasarkan jumlah hujan jam - jaman terekstrim pada 14 stasiun hujan di wilayah lereng Gunung Merapi dilakukan dengan bantuan perangkat lunak Surfer, sedangkan EWS berbasis intensitas hujan, dapat mengacu pada kurva garis kritis. Hasil penelitian menunjukkan intensitas hujan terbesar dengan nilai $>20 \mathrm{~mm} / \mathrm{jam}$ terjadi di stasiun hujan Gunung Maron. Dengan kumulatif frekuensi relatif intensitas hujan $>20 \mathrm{~mm} / \mathrm{jam}$ pada antara tahun $1988-2010$ sebesar $6,74 \%$. Analisis kejadian jumlah hujan jam - jaman terekstrim dari 14 stasiun hujan di Lereng Gunung Merapi tahun 1988 - 2010 terjadi pada stasiun Kemasan pada tahun 2010 sebesar 621.5 mm pada bulan Januari pukul 18.00 - 19.00. Critical Line Curve Kali Gendol di stasiun hujan Batur, Deles dan Sorosan, kejadian hujan non-causing rainfall pada dangerous area adalah 24 events (13,79\%), hujan causing rainfall pada dangerous area adalah 4 events $(2,30 \%)$ dan hujan non-causing rainfall pada safety area adalah 146 events (83,91\%). Kumulatif Frekuensi Relatif Intensitas Hujan > 20 mm/jam pada stasiun hujan yang dekat dengan Kali Gendol yaitu stasiun hujan Batur, Deles dan Sorosan dari level tinggi ke rendah masing masing adalah $2,74 \%, 2,33 \%$ dan $1,70 \%$.

Kata kunci: hujan ekstrim, intensitas hujan, sistem peringatan dini , kurva garis kritis.

\section{Pendahuluan}

Balai Penyelidikan dan Pengembangan Teknologi Kegunungapian (BPPTK) Yogyakarta, memperkirakan bahwa setelah erupsi Gunung Merapi tahun 2010 baru 10 persen dari sekitar 130 juta meter kubik material vulkanik yang terangkut oleh banjir lahar dingin. Oleh karena itu, masih besar kemungkinan terjadinya banjir lahar di masa yang akan datang [1-2].

Karakteristik hujan sangat bervariasi pada setiap daerah [3]. Dengan data hujan yang ada, maka dilakukan analisis sebaran hujan dengan membandingkan berbagai sifat hujan yang meliputi intensitas hujan, durasi hujan, jumlah hujan jam - jaman dan hujan bulanan. Pada penelitian ini, analisis karakteristik hujan ekstrim dilakukan untuk mengetahui pola sebaran jumlah hujan jam - jaman di wilayah lereng Gunung Merapi [4-5].
Untuk mengurangi dampak negatif akibat banjir lahar dingin, maka perlu direncanakan suatu sistem peringatan dini Early Warning System (EWS) dan tindakan evakuasi yang tepat. EWS berbasis intensitas hujan, dapat mengacu pada kurva garis kritis (Critical Line Curve) [6-7].

\section{Metode Penelitian}

\subsection{Lokasi Penelitian}

Lokasi penelitian adalah 14 stasiun pencatat curah hujan di wilayah lereng Gunung Merapi yang terletak di wilayah Provinsi Daerah Istimewa Yogyakarta, Kabupaten Klaten dan Kabupaten Magelang (Gambar 1). 14 stasiun di wilayah lereng Merapi, yaitu: Agromulyo, Babadan, Batur, Deles, Gunung Maron, Giri Kerto, Jrakah, Kaliurang Cepit, Kemasan, Ngepos, Pakem, Randu Gunting, Sorosan, dan Sukorini. 


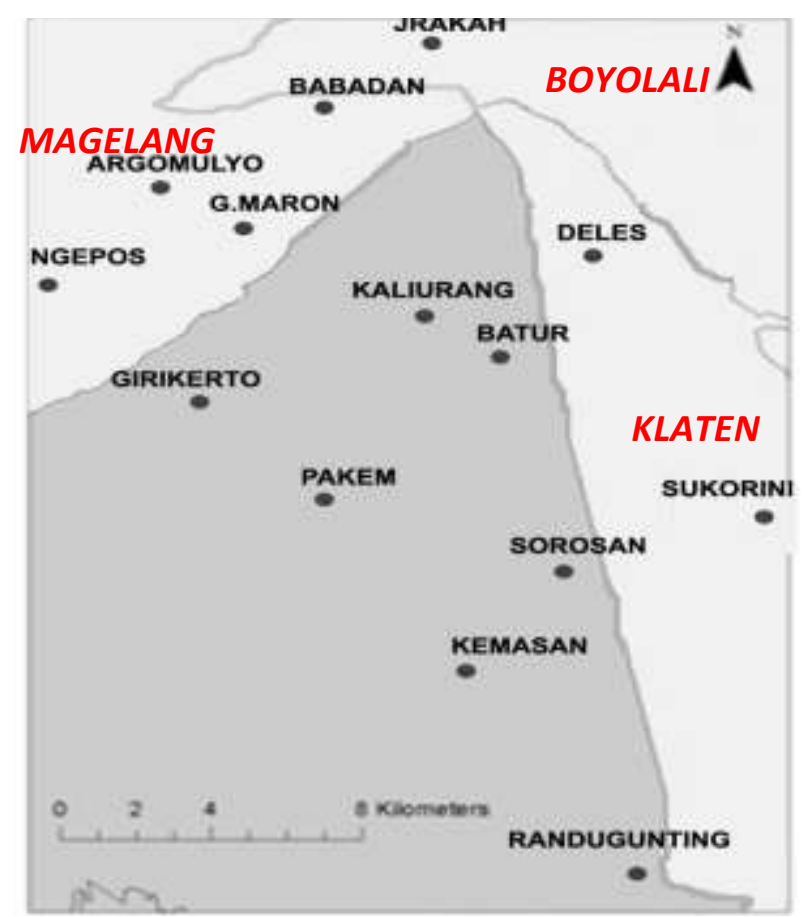

Gambar 1. Peta lokasi stasiun hujan

\subsection{Tahapan Penelitian}

Tahapan penelitian yang dilakukan pada analisis karakteristik hujan ekstrim untuk mendukung pengembangan peringatan dini lahar dingin di lereng Gunung Merapi ditunjukkan pada Gambar 2.

\subsection{Karakteristik Intensitas Hujan}

Karakteristik temporal intensitas hujan di wilayah lereng Merapi dapat dianalisa berdasarkan frekuensi kejadian yang dinyatakan dalam frekuensi relatif. Perhitungan frekuensi kejadian hujan relatif menggunakan rumus [8-13]:

$F R_{i}=\frac{f_{i}}{\sum f} \times 100 \%$

dimana:

$F R_{i}=$ frekuensi relatif kelas ke i,

$f_{i}=$ frekuensi kelas ke $\mathrm{i}$,

$i=$ indeks interval kelas.

Frekuensi relatif intensitas hujan dihitung dengan menjumlahkan hasil perhitungan frekuensi kejadian hujan relatif masing - masing stasiun selama jumlah tahun penelitian dibagi jumlah tahun. Hasil perhitungan dalam prosentase

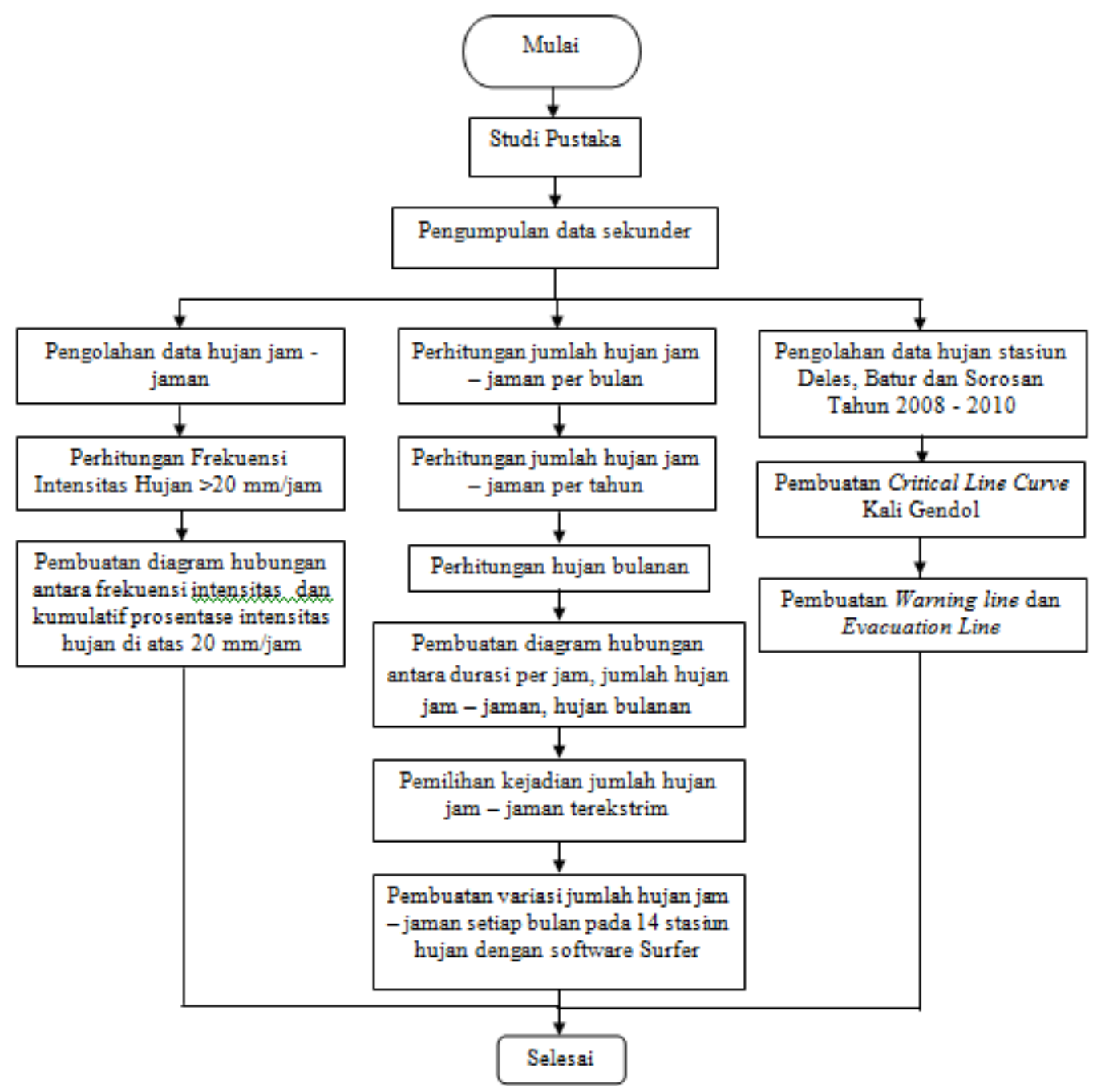

Gambar 2. Bagan alir penelitian 


\subsection{Karakteristik Spasial Intensitas Hujan}

Karakteristik spasial intensitas hujan di wilayah lereng Merapi dapat dianalisa berdasarkan pendekatan berikut ini.

1) Pola sebaran spasial durasi per jam, jumlah hujan jam jaman per durasi 1 jam setiap bulan dalam satu tahun, jumlah hujan jam - jaman per durasi 1 jam dalam satu tahun dan hujan bulanan.

2) Pola sebaran dilakukan dengan cara mengeplotkan data durasi per jam dan jumlah hujan jam - jaman per durasi setiap bulan dalam satu tahun dengan menggunakan software Surfer, dimana hasilnya nanti akan berupa grid yang menunjukkan sebaran jumlah hujan jam - jaman pada masing - masing stasiun hujan selama 23 tahun.

\subsection{Setting Critical Line Curve}

Pada penelitian ini setting Critical Line Curve menggunakan metode B. Hal ini disebabkan pada data aliran debris tersebut hanya tercantum tanggal kejadian aliran debris, sedangkan jam kejadiannya tidak tercantum. Metode A dapat digunakan jika diketahui jam kejadian aliran debris, karena pada sumbu Y metode A menggunakan intensitas hujan 1 jam sebelum terjadi aliran debris. Plot data sumbu X dan sumbu Y untuk $C L$ Curve Kali Gendol pada penelitian ini adalah sebagai berikut:

1) Urutkan data hujan jam - jaman berdasarkan waktu.

2) Hitung seri hujan dengan mengelompokkan data sesuai dengan seri masing-masing. Satu seri hujan adalah suatu rangkaian hujan yang diapit oleh tidak adanya hujan selama 24 jam atau lebih, sebelum dan sesudah rangkaian hujan tersebut. Walaupun jika terdapat data 0 mm (tidak adanya hujan) di antara dua curah hujan pada waktu yang berbeda, tetapi jika rentang waktu $0 \mathrm{~mm}$ tersebut kurang dari 24 jam, maka curah hujan yang bersebelahan waktu tersebut masih dalam satu seri hujan. Gambar 3 adalah contoh gambar skema rangkaian satu seri hujan.

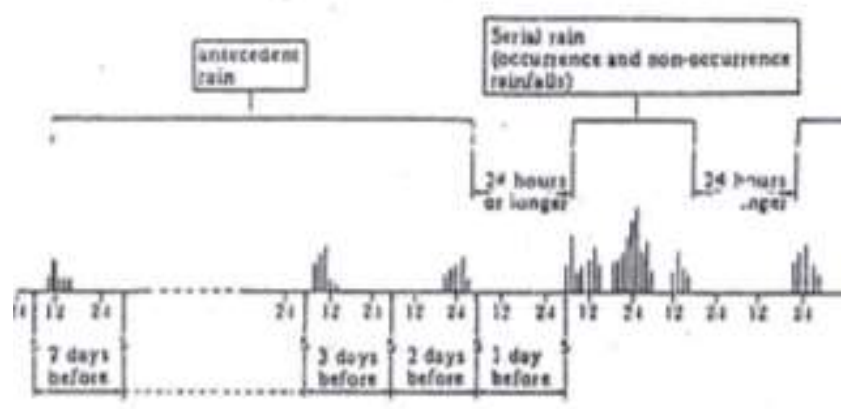

Gambar 3. Skema Rangkaian Satu Seri Hujan

Antecedent Working Rainfal (RWA) merupakan penjumlahan dari hujan yang terjadi pada $\mathrm{H}-1$ sampai $\mathrm{H}-$ 14 (antecedent rainfall) dari rangkaian hujan total dengan nilai $80 \mathrm{~mm}$. Dalam perhitungan RWA digunakan koefisien reduksi yang disebut $\alpha$, sehingga semakin jauh jarak kejadian antecedent rainfall dari kejadian hujan total, nilai koefisien reduksinya semakin. Rumus yang digunakan dalam perhitungan RWA adalah:
$R w a=0,25 d 2+0,125 d 3+0,0625 d 4+\ldots .(d 1=0)$

Untuk membatasi antara rangkaian hujan total dan antecedent rainfall maka disyaratkan 24 jam antara dua rangkaian hujan tersebut tidak boleh terjadi hujan sama sekali. Oleh karena itu nilai d1 disyaratkan $0(\mathrm{~d} 1=0)$. Working Rainfall (RW) merupakan penjumlahan antara RWA dengan hujan total pada rangkaian hujan yang ditunjukkan dengan rumus berikut ini [14-15].

$R W=$ Hujan Kumulatif $+R W A$

3) Menentukan titik infleksi A dan B seperti pada Gambar 4.

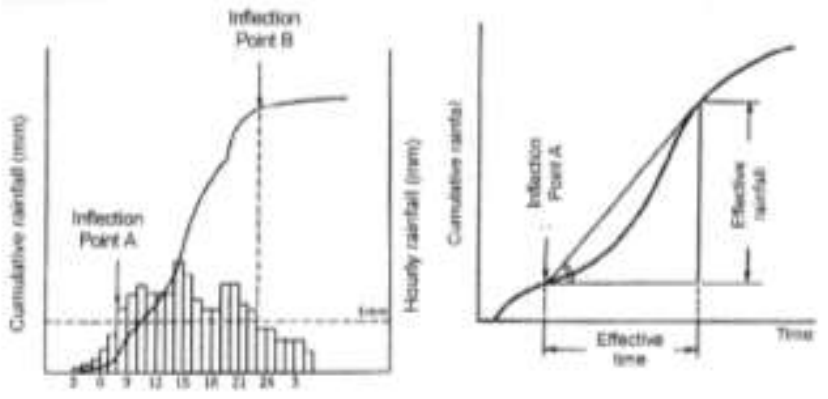

Gambar 4. Definisi Inflection Point A dan Inflection Point B

4) Plot RW pada sumbu $X$ dan intensitas curah hujan pada Sumbu Y. Plotting data untuk mendapatkan CL Curve ditunjukkan pada Gambar 5. Gambar 5 tersebut merupakan contoh pembuatan CL Curve. Pada metode $\mathrm{B}$, plot sumbu Y menggunakan intensitas hujan efektif seperti yang tertera pada Gambar 5.

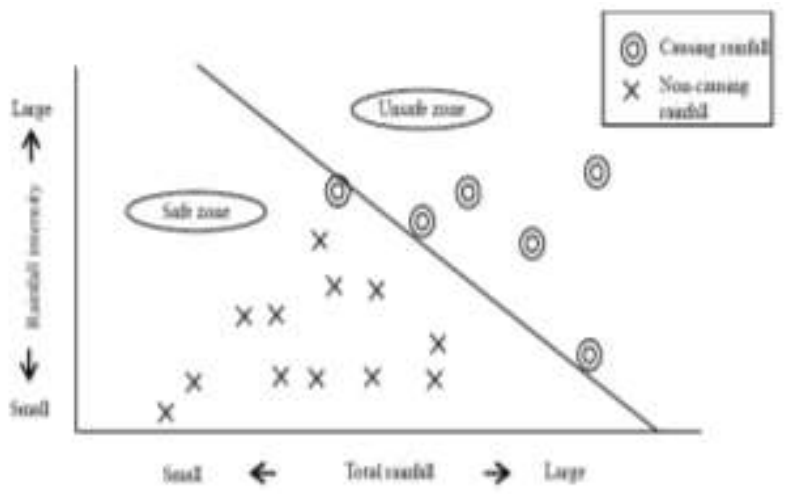

Gambar 5. Skema Setting Critical Line Curve

Garis kritis (CL Curve) dibuat dengan memisahkan kumpulan titik - titik causing rainfall dan non causing rainfall dengan suatu garis lurus. Persamaan dari garis CL Curve diasumsikan sebagai persamaan linier $\mathrm{y}=\mathrm{ax}$ $+\mathrm{b}$, dimana Y sebagai intensitas curah hujan efektif dan $\mathrm{X}$ sebagai working rainfall. Nilai $\mathrm{a}$ dan $\mathrm{b}$ pada persamaan linier dapat dihitung melalui 2 titik koordinat seperti pada Gambar 5. Pembuatan Garis CL Curve dibuat dengan ketentuan kemiringan $\alpha<-1$. Nilai $\alpha$ didapat dengan membagi y2 dan x1. 


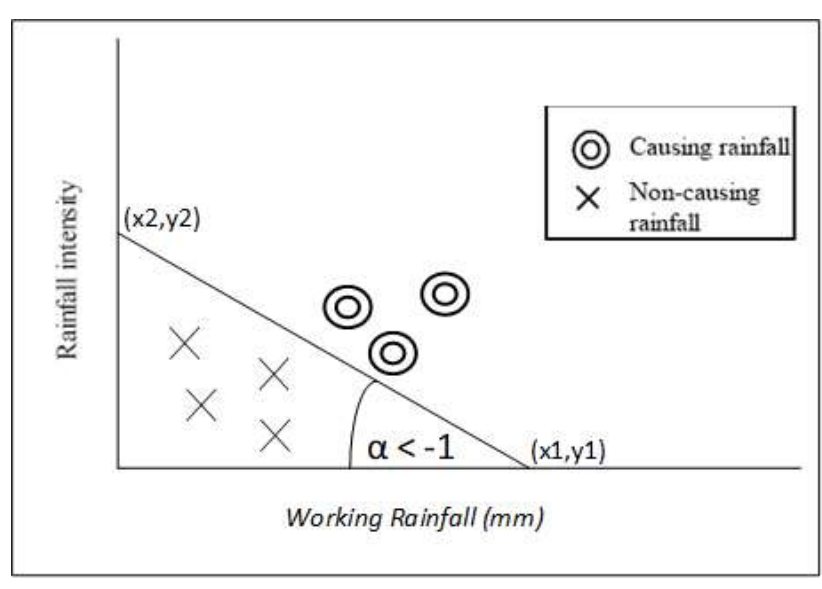

Gambar 6. Skema Pembuatan Garis Kritis

\section{Hasil dan Pembahasan}

\subsection{Perhitungan Kumulatif Frekuensi Relatif Intensitas Hujan}

Data hujan jam - jaman setiap tahun pada 14 stasiun hujan dihitung intensitas hujan ( $\mathrm{mm} / \mathrm{jam})$ dengan membagi kedalaman hujan dan durasi hujan. Sehingga didapat data intensitas hujan dengan nilai yang bervariasi. Setelah hasil perhitungan frekuensi intensitas hujan tiap tahun per stasiun hujan, kemudian dihitung prosentase frekuensi relatif masing - masing kelas interval. Karena penelitian lebih memfokuskan pada hujan ekstrim, maka kelas interval yang digunakan adalah kelas interval yang lebih besar dari 20 $\mathrm{mm} / \mathrm{jam}$. Berikut hasil perhitungan frekuensi relatif intensitas hujan pada seluruh stasiun hujan selama 23 tahun ditunjukkan pada Tabel 1 Contoh diagram kumulatif frekuensi relatif dapat dilihat pada Gambar 7 pada stasiun hujan Sorosan.

Tabel 1. Perhitungan kumulatif frekuensi relatif intensitas hujan $>20 \mathrm{~mm} /$ jam

\begin{tabular}{ccc}
\hline No & Stasiun & $\begin{array}{c}\text { Frekuensi Relatif } \\
\text { Intensitas Hujan>20 } \\
\text { mm/jam (\%) }\end{array}$ \\
\hline 1 & Agromulyo & 6,03 \\
\hline 2 & Babadan & 3,45 \\
\hline 3 & Batur & 2,74 \\
\hline 4 & Deles & 2,33 \\
\hline 5 & G. Maron & 6,74 \\
\hline 6 & Girikerto & 5,89 \\
\hline 7 & Jrakah & 2,09 \\
\hline 8 & Kaliurang Cepit & 3,95 \\
\hline 9 & Kemasan & 4,15 \\
\hline 10 & Ngepos & 5,83 \\
\hline 11 & Pakem & 2,30 \\
\hline 12 & Randugunting & 1,46 \\
\hline 13 & Sorasan & 1,70 \\
\hline 14 & Sukorini & 1,74 \\
\hline
\end{tabular}

Berdasarkan Tabel 1 dapat diketahui nilai kumulatif relatif intensitas hujan $>20 \mathrm{~mm} / \mathrm{jam}$ terbesar terdapat pada stasiun G.maron dengan nilai 6,74\%.

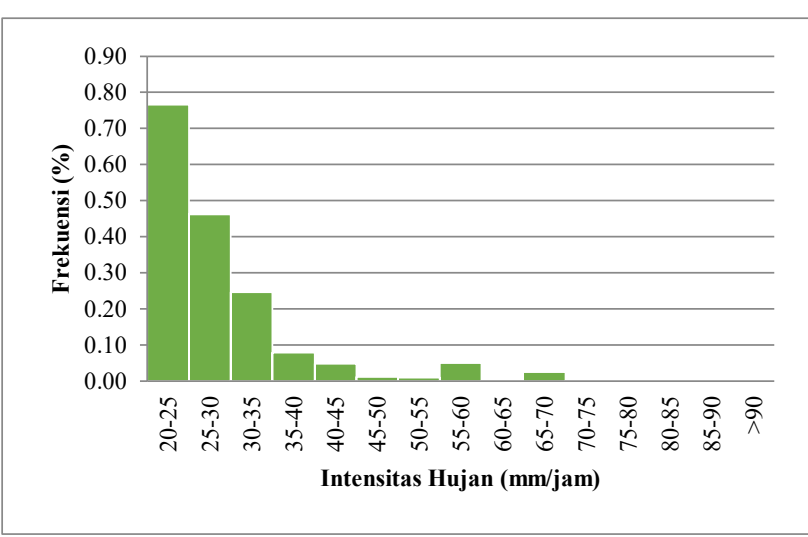

Gambar 7. Diagram kumulatif frekuensi relatif intensitas hujan Stasiun Sorosan

\subsection{Hasil Analisis Kejadian Jumlah Hujan Jam - Jaman Terekstrim}

Pada penelitian ini data yang digunakan adalah data hujan jam - jaman selama 23 tahun dari 14 stasiun hujan. Data hujan jam - jaman digunakan untuk membuat hubungan antara jumlah hujan jam - jaman per durasi setiap bulan dalam satu tahun, jumlah hujan jam - jaman per durasi dalam satu tahun dan hujan bulanan yang hasilnya nanti akan berupa grid yang menunjukkan sebaran jumlah hujan jam - jaman dengan durasi setiap 1 jam selama 24 jam pada masing - masing stasiun hujan selama 23 tahun. Setelah dilakukan pengolahan data hujan jam - jaman pada 14 stasiun hujan. Tabel 2 berikut ini adalah rangkaian kejadian hujan terekstrim dari 14 stasiun hujan di Lereng Merapi yang terjadi selama 23 tahun.

Tabel 2. Rekap Kejadian Jumlah Hujan Jam - Jaman terekstrim 14 Stasiun Hujan

\begin{tabular}{llllll}
\hline No & Stasiun & Tahun & Pmax & Bulan & Jam \\
\hline 1 & Agromulyo & 2008 & 271 & JUL & $09-10$ \\
\hline 2 & Babadan & 2008 & 295 & MAR & $16-17$ \\
\hline 3 & Batur & 1995 & 147.8 & NOP & $14-15$ \\
\hline 4 & Deles & 2003 & 174.2 & FEB & $15-16$ \\
\hline 5 & G. Maron & 1992 & 402 & JAN & $15-16$ \\
\hline 6 & Girikerto & 1990 & 223 & DES & $16-17$ \\
\hline 7 & Jrakah & 2007 & 155 & DES & $14-15$ \\
\hline 8 & Kaliurang & 1996 & 268 & NOP & $14-15$ \\
& Cepit & & & & \\
\hline 9 & Kemasan & 2010 & 621.5 & JAN & $18-19$ \\
\hline 10 & Ngepos & 1995 & 186 & FEB & $14-15$ \\
\hline 11 & Pakem & 1989 & 162.6 & FEB & $16-17$ \\
\hline 12 & Randugunting & 1994 & 137.4 & MAR & $15-16$ \\
\hline 13 & Sorasan & 2003 & 112.2 & FEB & $15-16$ \\
\hline 14 & Sukorini & 2003 & 102.5 & FEB & $15-16$ \\
\hline
\end{tabular}

Kemudian dilanjutkan dengan menganalisis kejadian jumlah hujan jam - jaman durasi 1 jam dengan membuat grid - grid pola sebaran jumlah hujan jam - jaman pada durasi selama 24 jam menggunakan Surfer. Berikut ini dapat dilihat contoh hasil interpolasi spasial pada Gambar 8 di stasiun hujan Kemasan tahun 2010.

Berdasarkan hasil pengolahan data hujan jam - jaman dari 14 stasiun hujan di lereng Merapi dan berdasarkan pola 
sebaran jumlah hujan jam - jaman, hujan paling sering terjadi sekitar bulan Januari dan Februari. Waktu kejadian hujan terjadi antara pukul $14.00-19.00$. Jumlah hujan jam - jaman terekstrim terjadi pada stasiun Kemasan pada tahun 2010 sebesar $621.5 \mathrm{~mm}$ pada bulan januari pukul $18.00-$ 19.00 .

\subsection{Hujan Jam - Jaman Terekstrim Critical Line Curve di Kali Gendol}

Pada pembuatan CL Curve data aliran debris yang dipakai adalah data aliran debris yang terjadi di Kali Gendol dari tahun 2008 samapai 2010. Data hujan yang digunakan adalah stasiun hujan yang dekat dengan kali Gendol yaitu stasiun hujan Batur,Deles dan Sorosan, dimana data hujan stasiun hujan tersebut akan dibagi menjadi data causing rainfall dan non - causing rainfall. Setelah dilakukan pengolahan data causing rainfall dan non-causing rainfall. CL Curve dibuat dengan pengelotkan Working Rainfall (RW) pada sumbu $x$ dan intensitas hujan efektif pada sumbu y. Hasil plot data non-causing rainfall dan causing rainfall ditunjukkan pada Gambar 9.
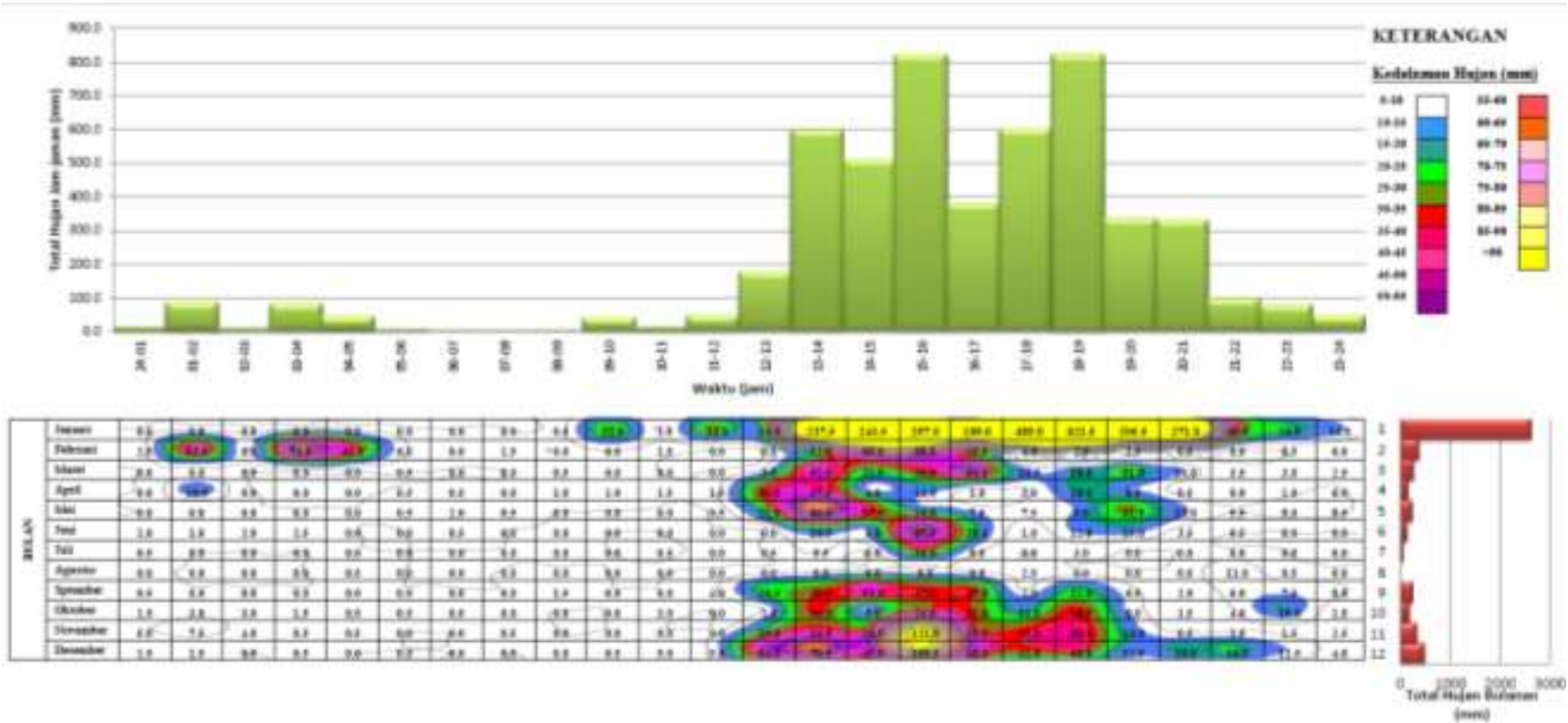

Gambar 8. Pola sebaran jumlah hujan jam - jaman Stasiun Hujan Kemasan

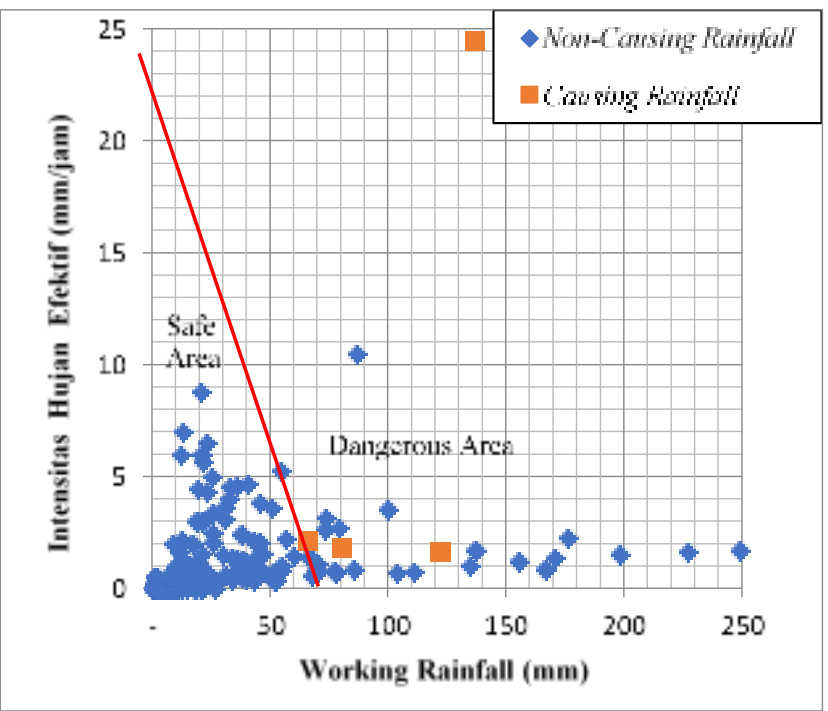

Gambar 9. Critical Line Curve Kali Gendol.

Pada CL Curve Kali Gendol tersebut antara non-causing rainfall dengan causing rainfall ditandai dengan simbol yang berbeda. Garis merah linier adalah garis kritis batas antara safety area dan dangerous area. Safety area menunjukkan jumlah kejadian hujan yang berada pada batas aman, sedangkan dangerous area menunjukkan jumlah kejadian hujan yang berada pada kondisi bahaya terhadap terjadinya aliran debris.

Penentuan Garis CL Curve antara non-causing rainfall dengan causing rainfall dibuat dengan ketentuan kemiringan $C L$ curve $\alpha<-1$. Berdasarkan persamaan garis linier didapat persamaan garis kritis pada $C L$ Curve Kali Gendol $y=-0,314 x+22$.

Berdasarkan persamaan garis kritis pada $C L$ Curve Kali Gendol tersebut, yaitu $\mathrm{y}=-0.314 \mathrm{x}+22$ dihitung prosentase titik dangerous area dan safety area. Diperoleh jumlah titik kejadian hujan non-causing rainfall pada dangerous area adalah 24 buah (13,79\%), hujan causing rainfall pada dangerous area adalah 4 buah $(2,30 \%)$ dan hujan noncausing rainfall pada safety area adalah 146 buah $(83,91 \%)$.

\section{Kesimpulan}

Setelah melakukan penelitian dan pembahasan tentang analisis karakteristik hujan ekstrim di Lereng Gunung, maka dapat diambil beberapa kesimpulan, dari 14 stasiun hujan di Lereng Gunung Merapi, intensitas hujan terbesar dengan nilai $>20 \mathrm{~mm} / \mathrm{jam}$ terjadi di stasiun hujan Gunung Maron. Dengan kumulatif frekuensi relatif intensitas hujan $>20 \mathrm{~mm} / \mathrm{jam}$ antara tahun 1988-2010 sebesar 6,74\%. Hasil analisis kejadian jumlah hujan jam - jaman terekstrim dari 14 stasiun hujan di Lereng Gunung Merapi tahun 1988 2010 dan berdasarkan pola sebaran spasial hujan ekstrim, jumlah hujan jam - jaman terekstrim terjadi pada stasiun 
Kemasan pada tahun 2010 sebesar $621.5 \mathrm{~mm}$ pada bulan Januari pukul $18.00-19.00$.

Berdasarkan hasil pengolahan data hujan jam - jaman dari 14 stasiun hujan di lereng Merapi dan berdasarkan pola spasial sebaran jumlah hujan jam - jaman, hujan paling sering terjadi sekitar bulan Januari dan Februari. Waktu kejadian hujan terjadi antara pukul 14.00 - 19.00. Pada pembuatan Critical Line Curve Kali Gendol di stasiun hujan Batur, Deles dan Sorosan. Jumlah titik kejadian hujan noncausing rainfall pada dangerous area adalah 24 buah $(13,79 \%)$, hujan causing rainfall pada dangerous area adalah 4 buah $(2,30 \%)$ dan hujan non-causing rainfall pada safety area adalah 146 buah $(83,91 \%)$. Penyebab terjadinya aliran debris tidak hanya karena curah hujan dengan intensitas yang tinggi, tetapi ada beberapa faktor lain penyebab aliran debris seperti kemiringan lereng, kondisi material sedimen di hulu dan lainnya. Titik kejadian non causing rainfall yang berada pada dangerous area, kemungkinan disebabkan oleh faktor lain selain curah hujan dengan intensitas tinggi, seperti kemiringan lereng dan kondisi material sedimen lahar

\section{Daftar Pustaka}

[1] Anonim, Pedoman Penyusunan Sistem Peringatan Dini dan Evakuasi untuk Banjir Bandang, Jakarta: Kementerian Pekerjaan Umum, 2012.

[2] Anomin, Development of Warning and Evacuation System Against Sediment Disasters in Developing Countries, Tokyo: Ministry of Land, Infrastructure and Transport Infrastructure Development Institute, 2004 .

[3] S.H. Brotowiryatmo, Hidrologi, Teori, Masalah, Penyelesaian, Jilid 1. Yogyakarta: Nafiri Offset, 2000.

[4] A. Amalia, Analisis Karakteristik Spasial Intensitas Hujan Wilayah Lereng Merapi, (Tugas Akhir), Jurusan Teknik Sipil dan Lingkungan, Yogyakarta: Fakultas Teknik, Universitas Gadjah Mada, 2011.

[5] A.G. Pradipta, Analisis Karakteristik Temporal dan Spasial Hujan Untuk Mendukung Kriteria Peringatan Dini Bencana di Wilayah Lereng Merapi (Tugas Akhir), Jurusan Teknik Sipil dan Lingkungan, Yogyakarta: Fakultas Teknik, Universitas Gadjah Mada, 2011.
[6] B. Triadmodjo, Hidrologi Terapan, Yogyakarta: Beta Offset, 2009.

[7] Daryono, Waspadai Ancaman Banjir Lahar Merapi di Puncak Musim Hujan, www.bmkg.go.id, 13 Juli 2012, Jakarta, 2011

[8] D.D. Prayuda, Analisis Karakteristik Spasial dan Temporal Hujan Ekstrim di Wilayah Lereng Merapi, (Tesis), Yogyakarta: Program MPBA Universitas Gajah Mada, 2012.

[9] I. Pabalik, N. Ihsan, and M, Arsyad, "Analisis Fenomena Perubahan Iklim dan Karakteristik Curah Hujan Ekstrim di Kota Makassar", Jurnal Sains dan Pendidikan Fisika, vol. 11, no. 1, p. 88, 2015.

[10] D.D. Prayuda, "Analisis Karakteristik Intensitas Hujan di Wilayah Lereng Gunung Merapi", Jurnal Rekayasa Infrastruktur, vol.1, no. 1, p. 14, 2015.

[11] T. Nuraya, A. Ihwan, and A. Apriansyah, "Analisis Hujan Ekstrim Berdasarkan Parameter Angin dan Uap Air di Kototabang Sumatera Barat", Prisma Fisika, vol. 4 , no. 1, p. $22,2016$.

[12] A. Djuraidah, C. Suheni, and B, Nabila, "Peramalan Curah Hujan Ekstrim di Provinsi Banten Dengan Model Ekstrim Spasial", Media Statistika, vol. 12, no.1, p. 50, 2019.

[13] A.N. Efendi, S. Kuncorojati, F.S. Budi, "Analisis Hujan Ekstrim Penyebab Tanah Longsor di Melawi Memanfaatkan Data Radar dan Satelit Cuaca (Studi Kasus Tanggal 28 Februari 2019)", Seminar Nasional Penginderaan Jauh, vol. 6, p. 195, 2019.

[14] F. Ghozalba, Analisis Regional Curah Hujan Berdasarkan Kurva Intensitas-Durasi-Frekuensi di Lereng Merapi, (Tesis), Yogyakarta: Program MPBA Universitas Gajah Mada, 2010.

[15] Y. Shuin, H. Shibano, and Haryanto, Temporal and Spatial Characteristics of Rainfall on the Southwest Slope of Mt. Merapi in Indonesia, Tokyo: Sabo Technical Centre, RIWRD, Ministry of PuBlic Works, Faculty of Agriculture, University of Tokyo, 2011. 